\title{
Clover species in grass-clover silages affects milk fatty acid composition*
}

\author{
H. Steinshamn ${ }^{1}$, E. Thuen ${ }^{2}$ and U.T. Brenøe ${ }^{2}$ \\ ${ }^{1}$ Bioforsk Organic Food and Farming Division \\ Tingvoll gard, N-6630 Tingvoll, Norway \\ ${ }^{2}$ Department of Animal and Aquacultural Sciences, The Norwegian University of Life Sciences \\ P.O. Box 5003, N-1432 Aas, Norway
}

\begin{abstract}
The objective of this study was to examine the effect of clover species on milk fatty acid (FA) composition. Lactating dairy cows were allocated to two groups and fed grass-clover silage containing either white clover (WC) or red clover (RC), without or with concentrate supplementation. No significant interaction of clover species with concentrate supplementation could be observed. RC milk had significantly higher proportion of polyunsaturated FAs $(\mathrm{P}<0.001)$, particularly $\mathrm{C} 18: 3 n-3$ $(\mathrm{P}<0.001)$, and contained a higher $n-3 / n-6$ FA ratio $(\mathrm{P}<0.05)$ than $\mathrm{WC}$ milk. It is concluded that $\mathrm{RC}$ silage, independent of concentrate supply, yielded milk with more beneficial FA composition than WC silage.
\end{abstract}

KEY WORDS: Trifolium repens, Trifolium pratense, silage, dairy milk, fatty acid, organic agriculture

\section{INTRODUCTION}

Feeding dairy cows silage made of white (Trifolium repens L.) or red (Trifolium pratense L.) clover has yielded milk with a high concentration of beneficial fatty acids (FA); red clover especially has given increase in levels of $\alpha$-linolenic acid (C18:3n-3) in milk (Dewhurst et al., 2003a). The effect of red clover is due to less extensive rumen biohydrogenation of $\mathrm{C} 18: 3 n-3$ than for grass or white clover (Dewhurst et al., 2003b; Lee et al., 2003). In the experiments of Dewhurst et al. $(2003 a, b)$ and Lee et al. (2003) the silages were made of pure clover, fed either solely or mixed with pure ryegrass silage when fed. In practise, it not advisable to grow legumes in pure stands or feed pure clover silages. It is also known that

\footnotetext{
* Supported by the Norwegian Agricultural Authority

${ }^{1}$ Corresponding author: e-mail: havard.steinshamn@bioforsk.no
} 
nutrient content and forage quality of grasses and clovers, particular grasses, may differ when grown in pure or mixed grass-clover stands (e.g., Lehman et al., 1978). The effect of a plant species grown in pure stands on milk quality is thus not necessarily the same as when those species are cultivated in mixed stands.

The objective of the work reported was to examine the effect of white cloverand red clover- grass silages, prepared from mixed grass-clover leys, on the fatty acid composition of milk fat.

\section{MATERIAL AND METHODS}

The experiment was carried out for two consecutive years (2004 and 2005) at the University of Life Sciences, As (Norway), during the first period of each of two lactations (first $89 \pm 16$ days in milk starting $16 \pm 11$ days post partum, with 4 groups of dairy cows fed two types of grass-clover silages without $(-\mathrm{C})$ and with ( $+\mathrm{C}=10 \mathrm{~kg}$ per day and cow) standard concentrate supplementation. The silage treatments were: grass-white clover round bales (WC) and grass-red clover round bales $(\mathrm{RC})$, both taken from the second and third cut. The grasses grown in mixture with the clovers in both treatments consisted of a mixture of Phleum pratense L., Festuca pratensis Huds., and Lolium perenne L. The crop and animal husbandry were managed according to organic standards.

For milk fatty acid analysis, 28 autumn-calving cows of the Norwegian Red Cattle breed were each year allocated to the 4 treatments, balanced for calving time and parity, leaving 7 cows per treatment. Milk samples were collected every 8 (2004) and 4 (2005) weeks for milk fatty acid analysis giving two and three samples per cow and year in 2004 and 2005, respectively.

Milk lipid was separated, followed by transmethylation to produce fatty acid methyl esters (FAME) according to Feng et al. (2004). Analyses to separate FAME were made by gas chromatography with a $200 \mathrm{~m}$ CP-Select CB for FAME capillary column (Varian Inc.)

Analysis of variance was conducted with year (2004 or 2005), silage type (WC or $\mathrm{RC})$, supplementation level $(-\mathrm{C}$ or $+\mathrm{C})$, parity ( 1 or $>1$ lactations), and lactation week as fixed effects, and animal within treatment and season as a random effect, accounting for covariation within animal in an analysis of repeated measures using SAS (1999). Reported estimates are LS means.

\section{RESULTS}

There was no statistical significant interaction of clover species with concentrate supplementation or year on the content of the individual FA. The effect of clover species was therefore similar at both supplementation levels and consistent across the two years. Thus, only the main effects will be presented. 
The silages were well-preserved (Table 1). The clover proportion was higher in $\mathrm{RC}$ than in $\mathrm{WC}$, but otherwise there were only small and mostly non significant differences in chemical composition $(\mathrm{P}>0.05)$.

Forage dry matter intake (DMI) was higher $(\mathrm{P}=0.038)$ on $\mathrm{WC}(13.6 \mathrm{~kg} \mathrm{DM} / \mathrm{d})$ than on $\mathrm{RC}(12.6 \mathrm{~kg} \mathrm{DM} / \mathrm{d})$. However, there were no significant differences in total DMI (17.5 vs $16.8 \mathrm{~kg} \mathrm{DM} / \mathrm{d})$ or milk production (24.8 vs $25.3 \mathrm{~kg} / \mathrm{d})$ for cows offered WC and RC diets.

Milk from cows offered RC contained significantly higher levels of C18:2n-6

Table 1. Chemical analysis of the silage

\begin{tabular}{lcccccc}
\hline \multirow{2}{*}{ Item } & \multicolumn{2}{c}{ Year 2004 } & & \multicolumn{2}{c}{ Year 2005 } \\
\cline { 2 - 3 } \cline { 5 - 6 } & WC & RC & & WC & RC \\
\hline Clover, g/100 g DM & $39^{\mathrm{b}}$ & $57^{\mathrm{a}}$ & & $30^{\mathrm{b}}$ & $40^{\mathrm{a}}$ \\
Dry matter, g/kg & $311^{\mathrm{a}}$ & $288^{\mathrm{b}}$ & & $265^{\mathrm{b}}$ & $281^{\mathrm{a}}$ \\
Crude protein, g/kg DM & 171 & 164 & & 152 & 148 \\
Ammonia-N, g/kg total-N & $78.3^{\mathrm{a}}$ & $67.4^{\mathrm{b}}$ & & 67.2 & 66.5 \\
Lactate, g/kg DM & 40.2 & 43.7 & & 59.8 & 59.3 \\
Total fatty acids (FA), g/kg DM & 11.1 & 11.8 & & 16.0 & 16.7 \\
C18:2n-6 linoleic, g/100 g FA & 14.3 & 14.4 & & 14.2 & 13.6 \\
C18:3n-3 linolenic, g/100 g FA & 34.9 & 35.0 & & 41.5 & 40.5 \\
\hline
\end{tabular}

$\mathrm{WC}=$ white clover - grass silage, $\mathrm{RC}=$ red clover - grass silage. Means on the same line within year carrying no common superscript are significantly different $(\mathrm{P}<0.05)$

Table 2. Effect of clover species $(\mathrm{WC}=$ white clover, $\mathrm{RC}=$ red clover $)$ in grass-clover silages on the fatty acid (FA) composition of milk fat ( $\%$ of total FA); average over 2 years and concentrate supplementation levels

\begin{tabular}{|c|c|c|c|c|}
\hline Fatty acid (FA) & WC & $\mathrm{RC}$ & SED & Significance \\
\hline $\mathrm{N}$ & 55 & 54 & & \\
\hline Short chain FAs, $(<\mathrm{C} 14: 0)$ & 14.3 & 14.2 & 0.32 & NS \\
\hline $\mathrm{C} 14: 0$ & 10.8 & 10.6 & 0.22 & NS \\
\hline C16:0 & 27.9 & 27.0 & 0.60 & NS \\
\hline $\mathrm{C} 18: 0$ & 10.1 & 10.4 & 0.30 & NS \\
\hline C18:1 cis -9 n-9 & 19.1 & 19.3 & 0.57 & NS \\
\hline C18:1 trans $-11 n-7$ & 1.73 & 1.81 & 0.074 & NS \\
\hline C18:2 cis-9, cis-12 n-6 & 1.04 & 1.12 & 0.036 & $*$ \\
\hline $\mathrm{C} 18: 2$ cis -9, trans $-11(\mathrm{CLA})+\mathrm{C} 20: 0$ & 0.97 & 0.97 & 0.033 & NS \\
\hline $\mathrm{C} 18: 3$ cis- 9, cis -12, cis $-15 n-3$ & 0.73 & 0.86 & 0.028 & $* * *$ \\
\hline $\mathrm{C} 20: 5 n-3$ & 0.104 & 0.113 & 0.0034 & $* *$ \\
\hline Sum saturated & 65.2 & 64.5 & 0.78 & NS \\
\hline Sum monounsaturated & 23.9 & 24.2 & 0.65 & NS \\
\hline Sum polyunsaturated & 2.84 & 3.09 & 0.069 & $* * *$ \\
\hline $\mathrm{C} 18: 3 / \mathrm{C} 18: 2$ & 0.77 & 0.84 & 0.033 & $*$ \\
\hline$n-3 / n-6$ & 0.83 & 0.91 & 0.034 & $*$ \\
\hline Apparent recovery of C18:2n-6 from feed to milk, $\%$ & 17.4 & 20.9 & 1.41 & $*$ \\
\hline Apparent recovery of $\mathrm{C} 18: 3 n-3$ from feed to milk, $\%$ & 8.9 & 11.9 & 0.65 & $* * *$ \\
\hline
\end{tabular}

NS $\mathrm{P}>0.1 ; * \mathrm{P}<0.1 ; * * \mathrm{P}<0.05 ; * * \mathrm{P}<0.01 ; \mathrm{P}<0.001$. SED $=$ standard error of the difference 
( $\mathrm{P}<0.05), \mathrm{C} 18: 3 n-3(\mathrm{P}<0.001), \mathrm{C} 20: 5 n-3(\mathrm{P}<0.001)$, polyunsaturated FA in total $(\mathrm{P}<0.001)$ and had increased $n-3 / n-6$ FA ratio $(\mathrm{P}<0.05)$ in comparison with cows offered WC (Table 2). The apparent recovery from feed to milk of C18:2n-6 and C18:3n-3 was higher on RC than on WC diets (Table 2).

Concentrate supplementation increased the content of C18:2n-6 (0.85 vs $1.30 \%$ of total FA; $\mathrm{P}<0.001$ ) but reduced the content of $\mathrm{C} 18: 3 \mathrm{n}-3$ ( 0.95 vs $0.64 \%$ of total FA; $\mathrm{P}<0.001)$ and the $n-3 / n-6$ FA ratio $(1.16$ vs $0.58 ; \mathrm{P}<0.001)$.

\section{DISCUSSION}

The higher content of polyunsaturated FA in milk from cows offered RC may be due to higher intake of these acids or less extensive biohydrogenation due to the activity of polyphenol oxidase, an enzyme and its substrate (phenols) present in high amounts in red clover. Lipolysis is a prerequisite for microbial hydrogenation of unsaturated fatty acids in the rumen. Lee et al. (2004) observed that the lipolysis in extracts of red clover leaves was reduced with increasing polyphenol oxidase activity. Dewhurst et al. (2003a) found higher apparent recovery of $\alpha$-linolenic acid from the diet into milk on red clover than on white clover silages, which could be explained by less biohydrogenation in red clover than in white clover (Dewhurst et al., 2003b). In the present study, the apparent recovery of $\alpha$-linolenic was also higher for RC than for WC diets.

Long chain FA, like the C18 FA, may be derived from mobilized fat during low energy supply (Palmquist et al., 1993), e.g., in early stage of lactation and/or with low concentrate supplementation as in the present study. On average, the cows gained weight during the experiment, and there was no significant difference between silage types in liveweight change (figures not shown). In addition, the difference between RC and WC in milk FA composition was similar at both concentrate levels. Thus, the increase of milk polyunsaturated FA, and particular $\alpha$-linolenic acid, on RC diet relative to WC diet was probably not due to differences in energy supply or FA intake but to less extensive rumen biohydrogenation.

\section{CONCLUSIONS}

Feeding red clover-grass silage resulted in a higher content of beneficial fatty acids, particularly $\alpha$-linolenic acid, in milk. 


\section{REFERENCES}

Dewhurst R.J., Evans R.T., Scollan N.D., Moorby J.M., Merry R.J., Wilkins R.J., 2003b. Comparison of grass and legume silages for milk production. 2. In Vivo and in sacco evaluations of rumen function. J. Dairy Sci. 86, 2612-2621

Dewhurst R.J., Fisher J.K., Tweed J.K.S., Wilkins R.J., 2003a. Comparison of grass and legume silages for milk production. 1. Production responses with different levels of concentrate. J. Dairy Sci. 86, 2598-2611

Feng S., Lock A.L., Garnsworthy P.C., 2004. Technical note: A rapid lipid separation method for determining fatty acid composition of milk. J. Dairy Sci. 87, 3785-3788

Lee M.R.F., Harris L.J., Dewhurst R.J., Merry R.J., Scollan N.D., 2003. The effect of clover silages on long chain fatty acid rumen transformation and digestion in beef steers. Anim. Sci. 76, 491501

Lee M.R.F., Winters A.L., Scollan N., Dewhurst R.J., Theodorou M.K., Minchin F.R., 2004. Plantmediated lipolysis and proteolysis in red clover with different polyphenol oxidase activities. J. Sci. Food Agr. 84, 1639-1645

Lehmann J., Bachmann F., Guyer H., 1978. Mutual influence of some clover and grass species with regard to their growth and their nutrient and mineral-content. J. Agron. Crop. Sci. 146, 178196

Palmquist D.L., Beaulieu A.D., Barbano D.M., 1993. Feed and animal factors influencing milk-fat composition. J. Dairy Sci. 76, 1753-1771

SAS, 1999. SAS User's Guide: Statistics, Version 8.01 Edition. SAS Inst., Inc., Cary, NC 